\title{
Aspects of Gastrointestinal Immunology and Nutrition in Human Immunodeficiency Virus-1 Infection in Brazil
}

\author{
Luiz RR Castello-Branco ${ }^{+}$, Maria Beatriz Ortigão-de-Sampaio
}

Laboratório de Imunologia Clínica, Departamento de Imunologia, Instituto Oswaldo Cruz, Av. Brasil 4365, 21045-900 Rio de Janeiro, RJ, Brasil

Mucosal surfaces have a fundamental participation in many aspects of the human immunodeficiency virus (HIV) infection pathogenesis. In Brazilian HIV-1 infected subjects, loss of weight and appetite are among the most debilitating symptoms. In this review we describe a defined mucosal immunogen that has profound but transient effects on HIV viral load, and we suggest that gut associated lymphoid tissue under constant immunostimulation is likely to provide a major contribution to the total levels of HIV. We also show that hypermetabolism appears to play a role in the wasting process in Brazilian patients coinfected with HIV and tuberculosis.

Key words: gastrointestinal immunology - human immunodeficiency virus-1 infection - nutrition mucosal immunology

The majority of human pathogens is predominantly encountered at mucosal surfaces (McGhee et al. 1992). Particularly, the gastrointestinal tract is under constant challenge by ingested foreign antigens in microorganisms or products of food digestion. This site is the largest accumulation of gut associated lymphoid tissues (GALT) in the body and contains inductive and effective structures which present integrated roles to ultimately create a protective mucosal immune response (Castello-Branco et al. 1996).

Mucosal surfaces are a major route of human immunodeficiency virus (HIV) invasion in sexual and vertical transmission. Mucosal sites may also contribute largely to the total reservoir of HIV particles since they contain more than $50 \%$ of the total body's immune cell pool (McGhee et al. 1992). In subjects who develop acquired immunodeficiency syndrome, severe immunossuppression predisposes mucosal sites to infections with a number of opportunistic pathogens leading to the characteristic morbidity of the syndrome, particularly respiratory and intestinal infections.

Loss of weight and appetite are among the most debilitating features in the natural history of HIV infection (Schwenck et al. 1993). In many developing countries, tuberculosis (TB) is the most frequent HIV-related opportunistic infection. Malnu-

\footnotetext{
${ }^{+}$Corresponding author. Fax: $+55-21-280.1589$

E-mail: branco@gene.dbbm.fiocruz.br

Received 7 August 2000

Accepted 4 September 2000
}

trition in $\mathrm{HIV}+\mathrm{TB}+$ subjects is severe and may contribute to increased morbidity and mortality in this group (Paton et al. 1999).

The state of cellular activation is fundamental for successful HIV replication (Zagury et al. 1986). It has been shown in vitro that engagement of adhesion molecules and release of activating cytokines during interaction with antigen specific T-cells enhances HIV replication in antigen presenting cells (Shattock et al. 1996). Exogenous challenges to the immune system of HIV-infected persons, such as opportunistic (Donovan et al. 1996) and bacterial infections (Bush et al. 1996) or parenteral immunisation (Staprans et al. 1995, Cheeseman et al. 1996, Stanley et al. 1996) have been shown to induce transient bursts of plasma viraemia in HIV-infected subjects. Likewise, it has been shown that CD4 counts decrease earlier in the intestinal mucosa than in peripheral blood (Lim et al. 1993). Thus, levels of immune activation may potentially affect disease progression, a possible explanation for the faster disease progression in sub-Saharan Africa, associated with a higher prevalence of infections, than in developed countries (Gilks 1993).

We have studied HIV-infected volunteers followed clinically at the Ambulatório do Banco da Providência, in Rio de Janeiro, Brazil (Ortigão-deSampaio et al. 1998). Combined whole cell-toxin B subunit oral cholera vaccine was used as a reproducible, safe and well defined model of gut immune stimulation for both HIV-infected and uninfected individuals (Lewis et al. 1994), which induces a local CD4-T-lymphocyte-dependent immune response (Hörnqvist et al. 1991) after which primed $\mathrm{B}$ and $\mathrm{T}$ cells migrate in peripheral 
circulation (Lewis et al. 1991, Castello-Branco et al. 1994). Twelve volunteers, receiving monoantiretroviral therapy (AZT or ddI), were immunised with one dose of oral cholera vaccine and five, with similar social background, antiretroviral treatment and CD4 counts, were mock-immunised as controls. Subjects were followed clinically by signs of adverse reactions or intercurrent syndromes associated with HIV-infection. Antibody immune response to cholera toxin and HIV load were assayed in plasma by ELISA (Lewis et al. 1991) and NASBA (Nucleic Acid Based Amplification, Organon Teknika), respectively. We observed a statistically significant transient increase in plasma viraemia, which was not accompanied by adverse clinical reactions, returning to baseline pre-immunisation values within two weeks. These findings clearly demonstrate that a defined acute mucosal immunogen has profound but transient effects on HIV viral load and suggest that GALT under constant immunostimulation is likely to provide a major contribution to the total levels of HIV. These results offer an explanation for the rapid decline in CD4 $\mathrm{T}$ lymphocites observed in the intestinal mucosal compared with declines seen in peripheral blood. Consequently, this could be a possible explanation for the fast progression of HIV disease in developing countries where intestinal infections are endemic. This was the first report of increase in plasma viral load following mucosal immune stimulation.

In another study conducted in Rio de Janeiro (Paton et al. 1999), we used reference water dilution methods to examine the body composition changes associated with TB and to assess the severity and pattern of wasting. Male patients who were HIV-positive and receiving treatment for active TB (HIVTB+) and HIV-infected controls without TB (HIVTB-) were studied. Total body water (TBW) and extracellular water (ECW) were measured by giving oral doses of deuterium oxide and sodium bromide, respectively, determining enrichment in plasma after $4 \mathrm{~h}$. Intracellular water (ICW), body cell mass (BCM), lean body mass (LBM) and fat mass (FM) were calculated from these parameters using standard equations. HIVTB+ $(\mathrm{n}=11)$ and HIVTB- $(\mathrm{n}=12)$ groups were similar in age, height, CD4 count and HIV risk factors. The results showed that HIVTB+ men had significantly lower mean ICW (13.2 versus $16.6 \mathrm{~kg}$; $\mathrm{p}=0.02)$ and $\mathrm{BCM}$ (18.4 versus $23 \mathrm{~kg} ; \mathrm{p}=0.02)$, a relative expansion of ECW (35 versus $30 \mathrm{l} / \mathrm{kg}$ body weight; $\mathrm{p}=0.04)$, and small and non significant reductions in total body weight (58 versus $62.1 \mathrm{~kg} ; \mathrm{p}=0.26$ ), LBM (45.5 versus $47.7 \mathrm{~kg} ; \mathrm{p}=0.33)$ and FM (12.5 versus $14.4 \mathrm{~kg} ; \mathrm{p}=0.51$ ) compared with HIVTBcontrols. BCM in the HIVTB+ group was similar to reference values for severe malnutrition. The relative depletion of BCM appeared excessive in comparison with reference values for uncomplicated starvation. We conclude that the nutritional status of HIVTB+ patients was significantly worse than HIVTB- patients. Malnutrition in HIVTB+ patients was severe and could contribute to decreased survival. Hypermetabolism appears to play a role in the wasting process in patients coinfected with HIV and TB.

With the use of new antiretrovirals since 1996, the patients we have been following at the Ambulatório do Banco da Providência and Casa de Acolhida Santo Antônio, both charitable institutions for treatment of homeless HIV-infected individuals, have presented less morbiditiy and mortality (Castello-Branco et al. 1998).

Currently, we are investigating the importance HIV subtype change followed by mucosal immune stimulation. We are also carrying out a prospective study on nutritional intervention in HIV infected subjects.

\section{REFERENCES}

Bush CM, Donovan RM, Markowitz NP, Kvale P, Saravolatz LD 1996. A study of HIV RNA viral load in AIDS patients with bacterial pneumonia. J Aids Hum Retrovirol 13: 23-26.

Castello-Branco LRR, Griffin GE, Poulton TA, Dougan G, Lewis DJM 1994. Characterization of the circulating $\mathrm{T}$-cell response after oral immunization of human volunteers with cholera toxin B subunit. Vaccine 12: 65-72.

Castello-Branco LRR, Lewis DJM, Ortigão-de-Sampaio MB, Griffin GE 1996. Gastrointestinal immune response in HIV infected subjects. Mem Inst Oswaldo Cruz 91: 363-366.

Castello-Branco LRR, Linhares-de-Carvalho MI, Ponce de Leon AC 1998. AIDS therapy in Brazil. Nature 392: 6675.

Cheeseman SH, Davaro RE, Ellison RT 1996. Hepatitis $\mathrm{B}$ vaccination and plasma HIV-1 RNA. $N$ Engl $J$ Med 334: 1272.

Donovan RM, Bush CM, Markowitz NP, Baxa DM, Saravolatz LD 1996. Changes in virus load markers during AIDS-associated opportunistic diseases in human immunodeficiency virus-infected persons. $J$ Infect Dis 174: 401-403.

Gilks CF 1993. The clinical challenge of the HIV epidemic in the developing world. Lancet 342: 1037 1039.

Hörnqvist E, Goldschmidt TJ, Holrnadahl R, Lycke N 1991. Host defence against cholera toxin is strongly CD4+ T cell dependent. Infect Immun 59: 36303638.

Lewis DJM, Gilks CF, Ojoo S, Castello-Branco LRR, Dougan G, Evans MRW, McDermontt S, Griffin GE 1994. Immune response following oral administration of cholera toxin B subunit to HIV-1-infected UK and Kenyan subjects. AIDS 8: 779-785. 
Lewis DJM, Novotny P, Dougan G, Griffin GE 1991. The early cellular and humoral immune response to primary and booster oral immunization with oral cholera toxin B subunit. Eur J Immunol 21: 20872094.

Lim SG, Condez A, Lee CA, Johnson MA, Elias C, Poulter LW 1993. Loss of mucosal CD4 lymphocytes is an early feature of HIV infection. Clin Exp Immunol 92: 448-454.

McGhee JR, Mestecky J, Dertzbaugh MT, Eldridge JH, Hirasawa M, Kiyono H 1992. The mucosal immune system: from fundamental concepts to vaccine development. Vaccine 10: 75-88.

Ortigão-de-Sampaio MB, Shattock RJ, Hayes P, Griffin GE, Linhares-de-Carvalho MI, Ponce de Leon A, Lewis DJM, Castello-Branco LRR 1998. Increase in plasma viral load after oral cholera immunisation of HIV-infected subjects. AIDS 12: 145-150.

Paton NI, Castello Branco LR, Jennings G, Ortigão de Sampaio MB, Elia M, Costa S, Griffin GE 1999. Impact of tuberculosis on the body composition of HIV-infected men in Brazil. J Aids Hum Retrovirol 20: 265-71.
Schwenck A, Burger B, Wessel D, Stutzer H, Ziegenhagne D, Diehl V, Schrappe M 1993. Clinical risk factors for malnutrition in HIV-1 infected patients. AIDS 7: 1213-1219.

Shattock R, Burger D, Dayer IM, Griffin GE 1996. Enhanced HIV replication in monocytic cells following engagement of adhesion molecules and contact with stimulated T cells. Res Virol 147: 171-179.

Stanley SK, Ostrowski MA, Justement JS, Gantt R, Hedayati S, Mannix M, Roche K, Schwartzerentruber DJ, Fox CH, Fauci AS 1996. Effect of immunization with a common recall antigen on viral expression in patients infected with human immunodeficiency virus type-1. N Engl J Med 334: 1222-1230.

Staprans SI, Hamilton BL, Follansbee SE, Elbeik T, Barbosa P, Grant RM, Feinberg MB 1995. Activation of virus replication after vaccination of HIV-1infected individuals. J Exp Med 182: 1727-1737.

Zagury D, Bernard J, Leonard R 1986. Long term cultures of HTLV-III infected T cells: a model of cytopathology of T cell depletion in AIDS. Science 231: 850-853. 